\title{
Продольное распределение температуры активного волокна в условиях генерации лазерного излучения
}

\author{
В.Е. Сыпин $^{1, *}$, Н.В. Воронков ${ }^{1,2}$, О.А. Рябушкин ${ }^{1,2}$ \\ ${ }^{I}$ Научно-техническое объединение «ИРЭ-Полюс» \\ ${ }^{2}$ ФИРЭ им. В.А. Котельникова РАН \\ *E-mail:vSypin@ntoire-polus.ru
}

DOI:10.31868/RFL2018.168-169

Выходная мощность современных волоконных лазеров достигает в непрерывном режиме генерации 10 кВт в случае одномодового излучения и 100 кВт в случае многомодового излучения. Увеличение мощности излучения волоконного лазера сопровождается усилением разогрева активной среды. Основной причиной нагрева активного световода является квантовый дефект разность энергии квантов накачки и генерируемого лазерного излучения, которая преобразуется в тепловую энергию. Дополнительный разогрев волокна происходит также вследствие пассивных потерь излучения накачки и генерируемого излучения, неупругого рассеяния и различных безызлучательных процессов.

Разогрев активного волокна приводит к изменению сечений поглощения и люминесценции активных ионов, что влечет за собой изменение параметров работы лазера: уменьшение выходной мощности излучения, увеличение порога генерации [1]. Увеличение мощности лазерного излучения увеличивает разогрев активного волокна, а это приводит и к изменению волноведущих свойств волокна, что влечет за собой изменение модового состава излучения, а также к деградации защитной полимерной оболочки волокна. Таким образом, температурный контроль является важной задачей для создания источников мощного лазерного излучения, а также для проведения различных температурных исследований активных волокон.

На данный момент в мировой литературе предложено несколько различных способов измерения температуры активного волокна ([2],[3]). Оригинальная методика измерения температуры полимерного покрытия активного волокна недавно была предложена в работе [4].

В предлагаемой работе разрабатывается новый способ измерения температуры активного волокна в условиях генерации или усиления лазерного излучения. Упрощённая блок-схема экспериментальной установки представлена на рис 1.

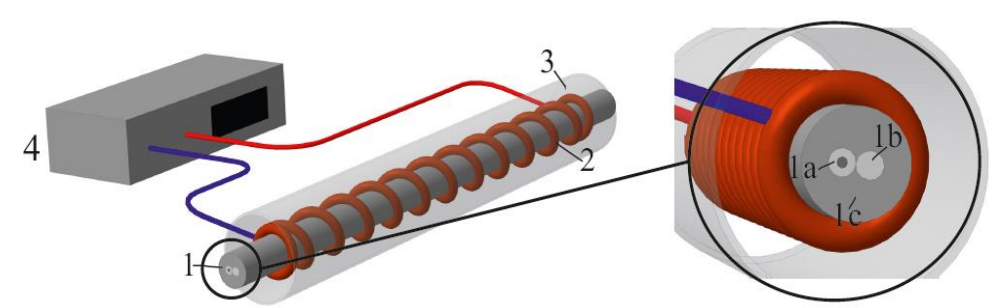

Рис. 1. Схематический участок активного волокна с металлической проволокой.

В данной работе использовался известный тип активного волокна DSCCP (Distributed Side-Coupled Cladding-Pumped) более распространённое название GTWave волокно [5]. Вокруг полимерной оболочки активного волокна в виде 
отдельных отрезков намотана тонкая металлическая проволока. На рис. 1 схематично представлен участок активного волокна с проволокой, где 1а волокно с жилой, легированной редкоземельными ионами, $1 \mathrm{~b}$ - волокно для многомодовой накачки, 1с - полимерная оболочка, 2 - медная проволока, 3 теплоизолирующий цилиндр для уменьшения воздействия внешней среды на участок активного волокна (на волокне намотано $\mathrm{N}$ отрезков проволоки), 4 миллиометр.

Во время лазерной генерации происходит разогрев полимерной защитной оболочки активного волокна, вследствие чего происходит изменение электрического сопротивления металлической проволоки, находящейся в тепловом контакте с полимерной оболочкой. При измерении сопротивления (что легко осуществимо при помощи использования современных миллиомметров или мостовых схем) с высокой точностью определяется температура каждого отрезка проволоки. Эти данные использовались для теоретической оценки температуры жилы. На рис. 2 представлены расчетные значения продольного распределения температуры жилы при разных уровнях накачки эрбиевого лазера (в качестве активного волокна использовалось кварцевое волокно, легированное ионами иттербия и эрбия, резонатор образован двумя волоконными брэгговскими решетками, длина волны излучения накачки - 960 нм).

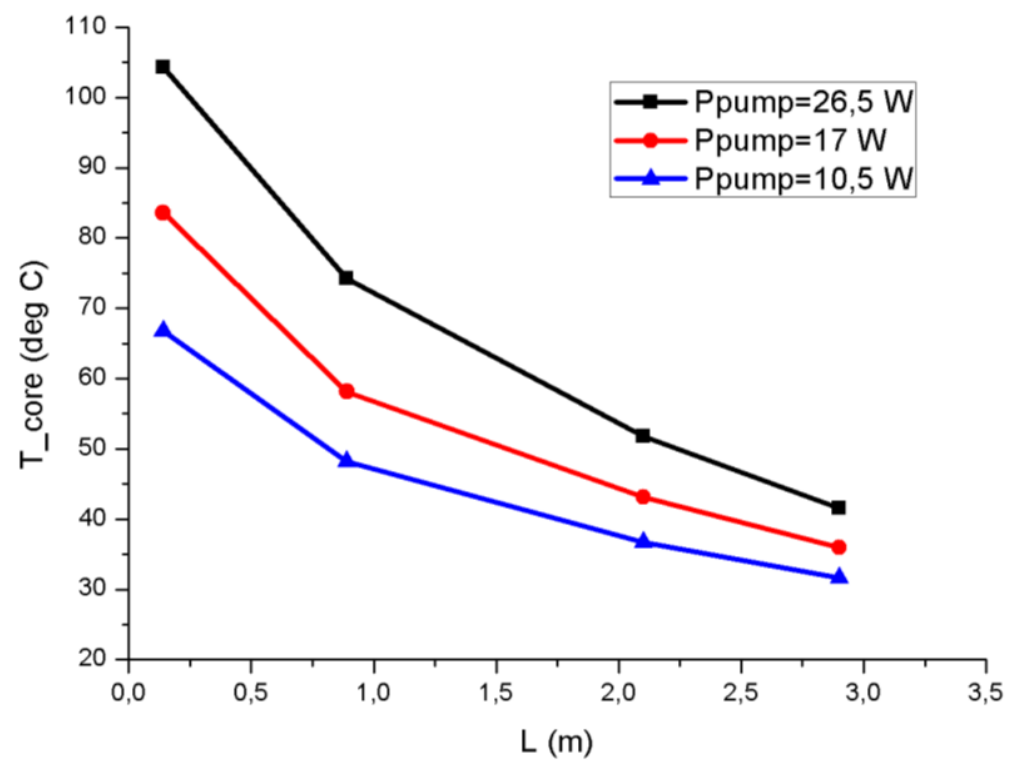

Рис. 2. Продольное распределение разогрева проволоки при разных уровнях мощности накачки эрбиевого волоконного лазера.

В будущем требуется дальнейшее уточнение теоретической модели.

\section{Литература}

[1] N. Brilliant, K. Lagonik, Optics Letters 26, 1669-1671 (2001)

[2] F. Beier et al., Advanced Solid State Lasers (OSA), ATh2A.23 (2015)

[3] Y. Jeong et al., Optics express 16, 19865-19871 (2008)

[4] O. Ryabushkin, R. Shaidulin, I. Zaytsev, Optics letters 40, 1972-1975 (2015)

[5] A. Grudinin et al., US patent № 6826335 (2004) 